\title{
少量製茶法の研究*
}

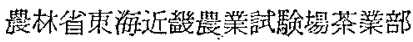

桑原 穆夫 ・横沢 光㳇

\section{Studies on a Miniature Tea Manufacturing Process}

By Yoshio Kuwabara, Mitsuo Yokozawa, and Yukitaka SuzukI

\section{1. 緒言}

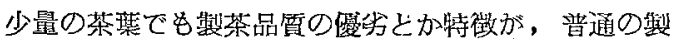
茶蟣㽣による製品亡同じように鑑別でされば，茶の育種 や製造試験が容易々なるのでその意義は大きい。よつて 筆者等は，てれが解決飞梁い関心を等せて研究をすすめ ていたが，煎茶及び玉綠茶てついて蜼，詿作した小型製

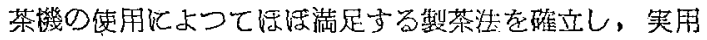
に移すことができえ。

てこに試作機と，その使用法及び製品の特徽の概要を

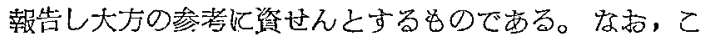
の研究の実湖については，整茶第一研究空の全員並びに
寺因製茶機㹕作所の協力によるところが大きくここに記 し感謝をする。

\section{2. 試作機とその構造}

機峨の容量は，数回の普通審查化必要な製茶を得るこ

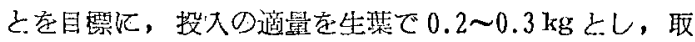

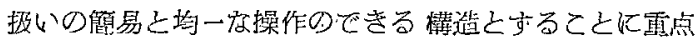

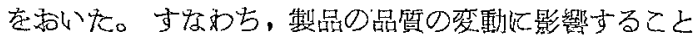

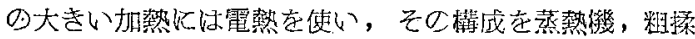

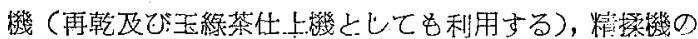

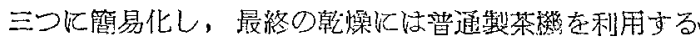

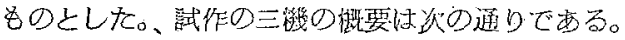

第 1 図蒸器 (A 機)

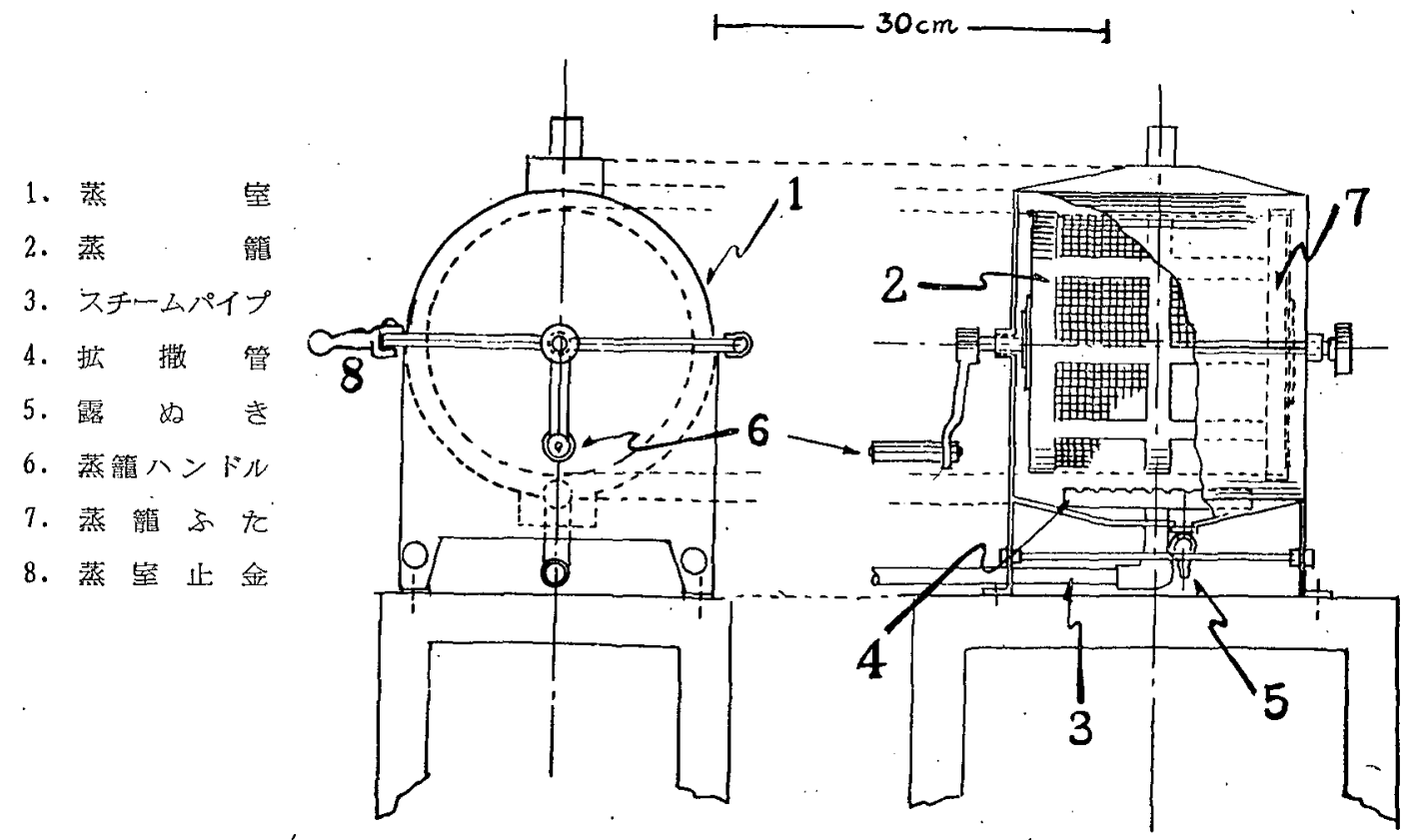

1. 蒸熱機 ( $\mathrm{A}$ 機と呼称する) .

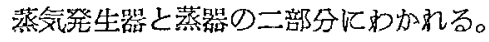
藻気発生器：常用容水量 7 几のたて型鋼板製小型電熱 ポイラーで，加熱には $4 \mathrm{~kW}$.の麗熱を使つた。

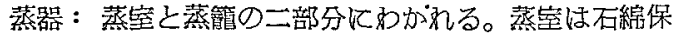

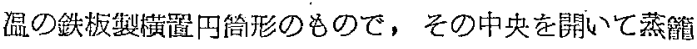
の装入取出の便をは加つた。蒸気は下部の掋散管から暨

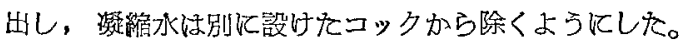

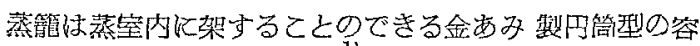

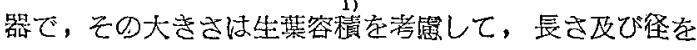

*荣業技術研究 No.13 32 38 (1955) より転載 **元茶業部技官 
各 $200 \mathrm{~m}$ mim とし\%。なお，容器の禹側は一方を投入口に 当て、てれにはふたを附し，いま一方注固定で，乙れ记

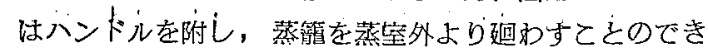
るもの゙とした。(第主图)

\section{2. 粗揉譏 (B嘰之呼称する)}

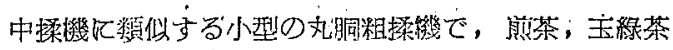

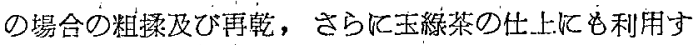

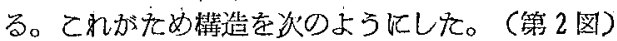

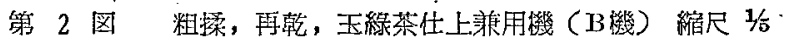

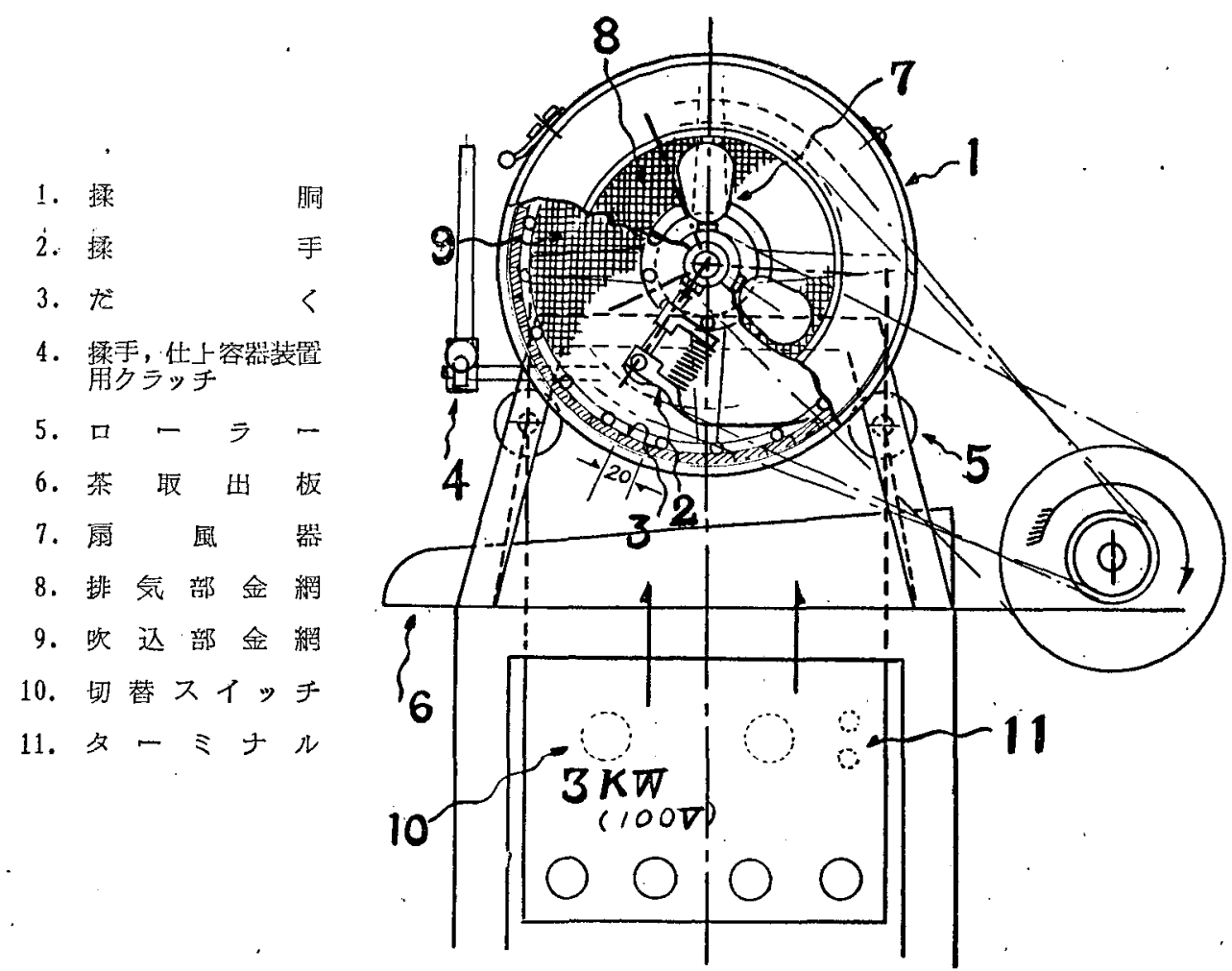

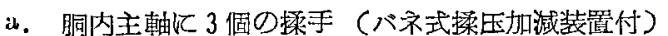
を附したが，乙の搡手はカラ型再乾または玉綵茶の仕上 として利用するとさ纪は，クラッチ揉作で簢単に取りは ずしができるようにした。

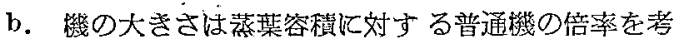

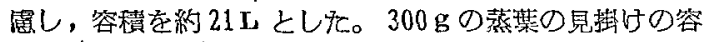
䅡飞対する倍率注約 4.5 咅で, 同の長さ及び径を $300 \mathrm{~mm}$ 比充。

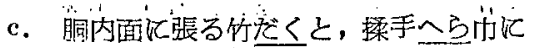

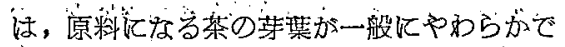
小さいすの移いととを予想して，普通機よ

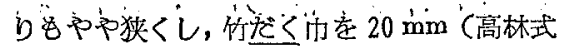
粗揉機の 8/10)，揉手へ占币を $48 \mathrm{~mm}$ '(高标 式粗操機の $8 \% 10$ ) とした。

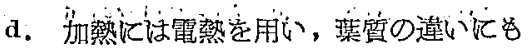

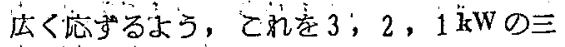
段町替型とし无。

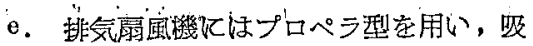
引量の調節まその兾面角度の变化で行うるう kliz。
チ。胴，揉手の迴転は駆動プーリーを経てあたえられ るが，茶の引上げ莸転位置を考慮し，標準として胴速を $35 \mathrm{r} . \mathrm{p} . \mathrm{m}$, 禁手を $55 \mathrm{r} . \mathrm{p} . \mathrm{m}$ とした。

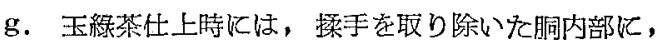
茶を入れたそろ沉ん珠型容器をクラッチ操作で取り付け 整形乾蜗を施すようにした。(第3図)

3. 精抒機 (C㙨と呼称する)

第3図玉綠茶仕上容器

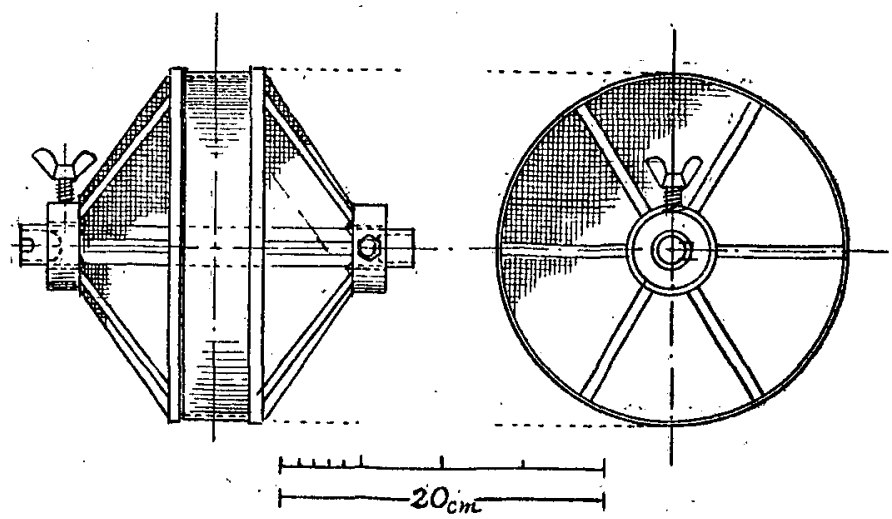


既存の精揉機を小さくしそものであるが，投入量の少

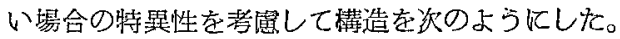

a，投入量が少いと外乾きすることが多いので，普通

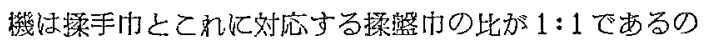

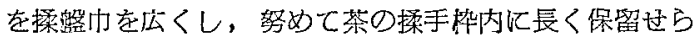
れるようにした。

b，揉手和よび探幋等の主要部の大きさは，普通禨(小

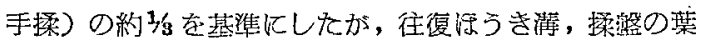

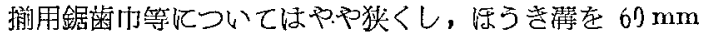
(八木・寺日式精揉機の910)，鉛药门を $16 \mathrm{~mm}$ (八木・ 寺田式精搡機の \%

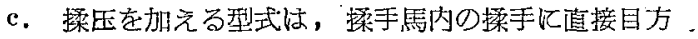

の加わるいるするる分銅型を用い，最高を $0.05 \mathrm{~kg} / \mathrm{cm}^{2}$ と Li。

d，揉手扮よび葉ざらいと，てれに対応する揉盤の間

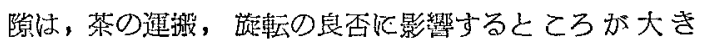

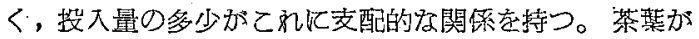

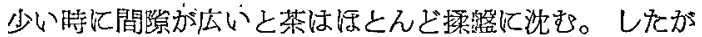

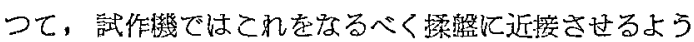
にし，中山と揉手突部の間隙を $5 \mathrm{~mm}$ としたが，乙の值 は普通機の約 16に相当した。

e，外乾きするのは精搡末期の現象であるので，揉釜

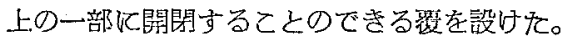

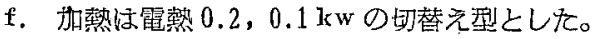

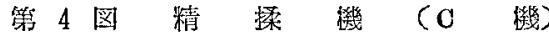

1. 手

2. 往復ぼき

3. 藮さらい

4. 揉手练うき用クラン クとロッド

5. 分

铜

6. $と$

7. 势釜此め

8. 電熱ターミナル

9:スイッ 于

10、はき込みほうき

11. 覆

12. 分銅加け

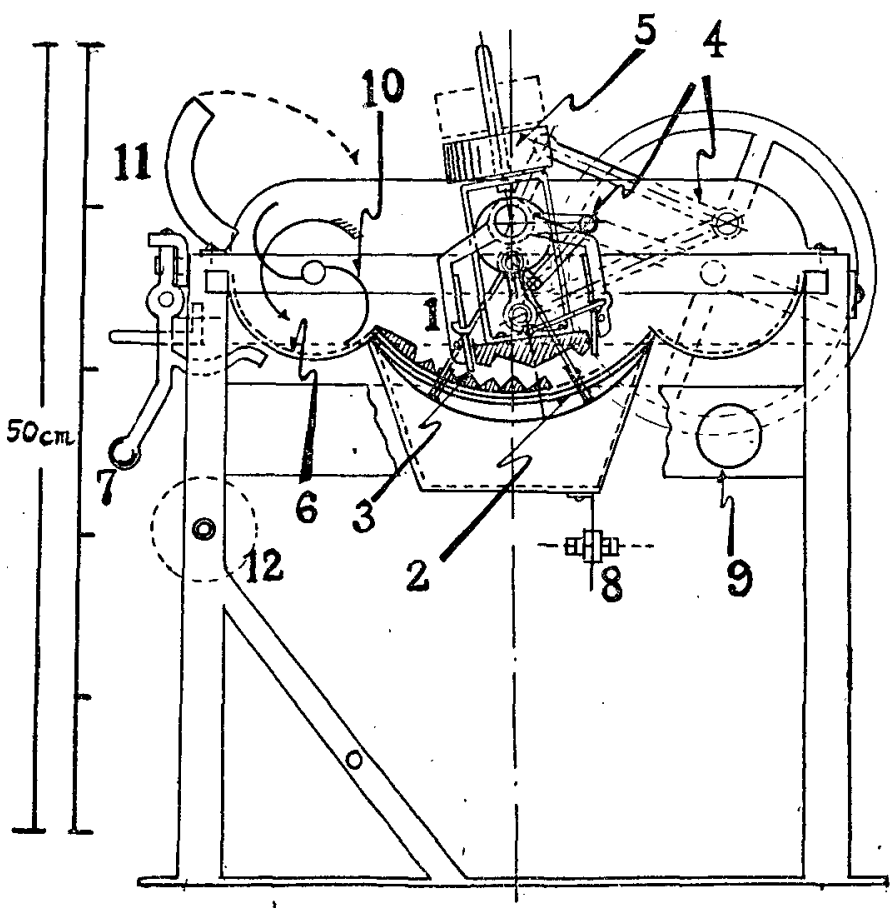

\section{3. 製茶法と备操作の標凖}

試作耭の適当な使用法は大体普通機を 使う場合の要領 に準ずればよいが，取扱いの旊易と操作の均一な進行が はかれるようにしたため，標倠を次のように設定した。 蠗茶工程は次の通り。

\begin{tabular}{|c|c|c|c|c|}
\hline 蒰 茶 & 蒸熱 & $\rightarrow$ 粗策, 再䓂 & $\rightarrow$ 精揉 & $\rightarrow$ 乾㖟 \\
\hline & A 䟼 & B蟣 & $\mathbf{C}$ 僟 & 糪蓺殹いる \\
\hline 䄸 & 蒸㙨 & 粗揉, 再乾 & 仕上 & 乾燥 \\
\hline & A 機 & B機 & $\mathbf{C}$ 機 & 電熱活し \\
\hline
\end{tabular}
各操作の概要は次の通り。

1. 蒸熱

ポイラー压汃 $1.5 \mathrm{~kg} / \mathrm{cm}^{2}$ 亿上昇したとき，此升を開

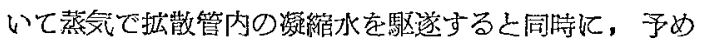
蒸空を加温しておく。続いて茶祡の入つた蒸籍を架し， 蒸空を閉めてから蒸気を送る。蒸熱が不均一にならない

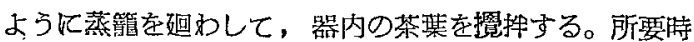
間は禁質によつても違うが，ボイラー匞を $1.5 \mathrm{~kg} / \mathrm{cm}^{2}$ (蒸発水量二的 $150 \mathrm{cc} / \mathrm{min}$ ) 保つて20 30秒である。

\section{2. 粗媃・再乾}

煎葉，玉線茶ともに長特間粗揉と双なされる簡略法を 用いる。すなわち，茶装は粗搡程度まで搡まれ乾燥は進 んでいても取り出さす，そのまま再乾をする方法で，加

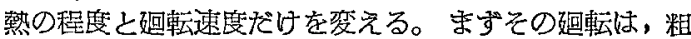
探㭙の䏤速 35 r.p.m を再乾では 30 r.p.m K，加熱杖茶

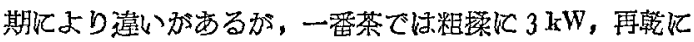

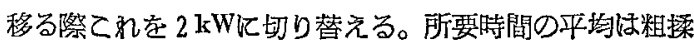


飞20分, 再乾飞 5 分, 計25分で, その間茶葉は重量減60 \%を示す程度に乾燥する。

この 60\%重量減恃，普通機化よる再乾後の状態よりも やや若いが，訌作の精揉機，仕上機伎入するものの取 出度として注適度となる。

\section{3. 精 琭}

操作の要領は普通機を使う場合と大䒰がない。電熱を

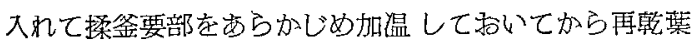
を入れる。䢙転は投入の当初が $30 \mathrm{r} . \mathrm{p} . \mathrm{m}$ ，乾䑁が進えだ ところでやや落す医うが成瞔はよい。加压法塊にならな い程度で狳方にしめ込む。したがつて，分銅をのせる时 期及び方法も普通僟を使う場合と变らないが，ただ少䁷 の茶を揉む場合の特異性として，どうしても空気化触れ る機会が多くなるために，外畭きにより茶の肌が莎れて くる。乙れを防ぐには嘰内湿度を高くすることが効果的 でありその末期汇覆を施す必要を認めた。

\section{4. 纴上}

玉線茶の整形が主目的で 仕上器の中に再乾琵を入れ，

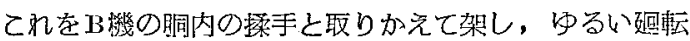
(20 r.p.m) で乾燥する。換気が强いと茶のしまりが覀 くなるので, 彨風㙨はこの埸合止める。

5 . 乾燥

普通の製茶用酸燥機を使うこととしたので 試作せず，

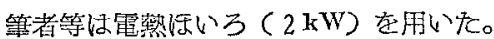

\section{4. 圾 験 成 續}

\section{1. 製茶品誓とその特徽}

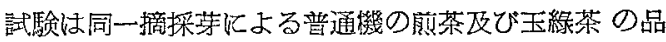

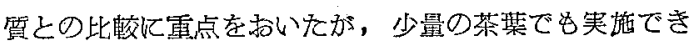
る二，三の簡易处理法の効果も確めたいと考え，乙れを

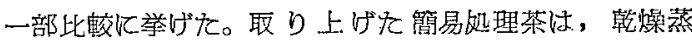

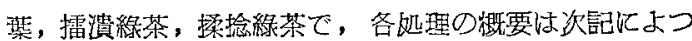
\%。

乾燥蒸堞：蒸葉を揉まずに淔ちに乾燥するす法で，供 試量を $100 \mathrm{~g}$ とし，乾燥機には谷田式電熱乾燥機を使つ た。

擂潰綠茶：足立Eの変法で，100g の蒸禁を前記谷田 式乾燥㙨で的 50\%重量減になるまで乾燥し，続いて擂皘 11号篩下とし，再び前記乾焒機に 杘して完全に畭學す る。擂㵋機には石川式を主軸 28 r.p.mで 10 分間使つ t。

揉捻線茶： $300 \mathrm{~g}$ の蒸琹を重量減約 $50 \%$ まで前記乾燥 㙨で颠燥し，乙れを小型䍒捻機で 5 予間揉捻し，再び同 乾燥機に帍して完全に乾熛する。

品質の比睖は主として普通寒查法によつた。 第 1 表は 1952 年の成績である。值は 3 回反覆製造した製品の平均 で，各項目の满点を20として採点した。な稀，同年度似 称いてはの機の試作は間化合わねかつた。

第 1 表 審 查成 績 (1)

\begin{tabular}{|c|c|c|c|c|c|c|c|c|c|c|c|c|c|c|c|c|c|c|}
\hline 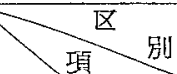 & & 培 通 & 幾 & 玉 & 線 茶 & & & 少 量 & : 機 & 玉 & 綠 节 & & & 乾 & 燥 & 蒸 & 樊 & \\
\hline 频负月 & 形状 & 色沢 & 水色 & 香気 & 滋味 & 計 & 形状 & 色沢 & 水色 & 香気 & 滋味 & 計 & 形状 & 色浱 & 水陆 & 香気 & 滋味 & 計 \\
\hline 5. & 17 & 15 & 14 & 16 & $15^{\circ}$ & 77 & 15 & 15 & 14 & 14 & 14 & 72 & - & 14 & 13 & 13 & 13 & - \\
\hline $5 . .15$ & 14 & 15 & 14 & 16 & 14 & 74 & 13 & 15 & 14 & 14 & 13 & 69 & - & 13 & 12 & 13 & 11 & - \\
\hline 7. & 11 & 12 & 13 & 12 & 12 & 63 & 12 & 12 & 12 & 11 & 11 & 58 & - & 13 & 10 & 12 & 10 & - \\
\hline 7. & 13 & 11 & 12 & 12 & 12 & 60 & 11 & 10 & 11 & $1 \cdot 1$ & 11 & 53 & - & 10 & 10 & 11 & 9 & 一 \\
\hline 18 & 14 & 14 & 12 & 13 & 11 & 64 & 14 & 13 & 13 & 12 & 10 & 62 & - & - & - & - & - & - \\
\hline 20 & 13 & 13 & 13 & 13 & 12 & 64 & 12 & 13 & 13 & 13 & 12 & 63 & - & - & - & - & - & - \\
\hline
\end{tabular}

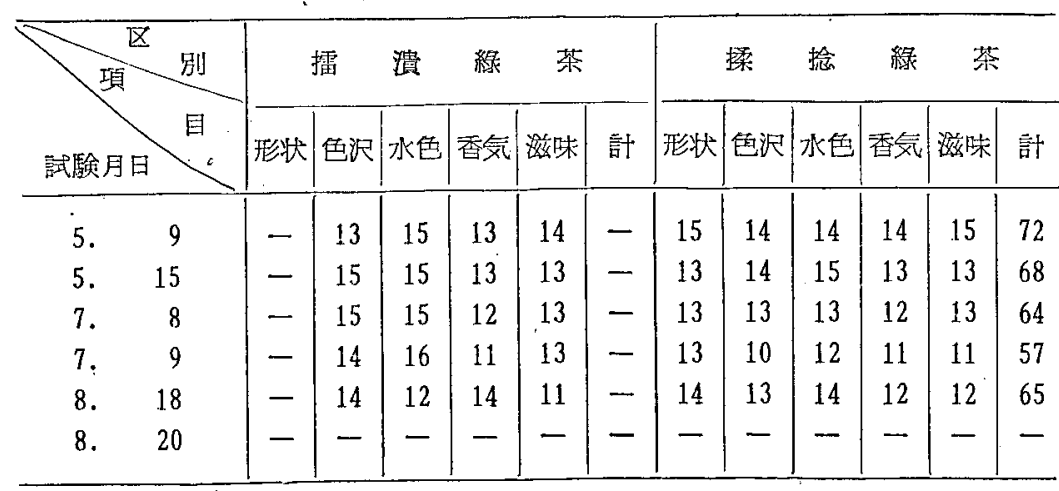

墴考：各茶期初，中期の在来種手摘芽を使つた。普通烧玉綠茶は，茶業部その一 鈭法で，3 貫斥を単位とした。
第 2 表は1953年度の成績で, 同年には簡易姏理として乾燥蒸 棐のみ取りあげた。採点並びに 供試原料は前年度に準じた。

結果の概要を述べると，少量 耭製茶は前茶，玉綠荣飞和いて ともに形状，色沢が対照の普通 譏製品にや防る。しかし，他 の項目では情とんど恙がなく， 採点は全項目にわたつて強い正 の相関関䋆を示した。簢易如理 茶も色沢ではかなり密接な関係 
第 2 表審查成績 (2)

\begin{tabular}{|c|c|c|c|c|c|c|c|c|c|c|c|c|c|c|c|c|c|c|c|}
\hline \multirow{2}{*}{\multicolumn{2}{|c|}{ 顶 }} & \multicolumn{3}{|c|}{ 普 通 } & 幾 & \multicolumn{2}{|c|}{ 前 茶 } & \multicolumn{2}{|c|}{ 少 } & 量 & \multicolumn{3}{|c|}{ 煎 茶 } & \multicolumn{3}{|c|}{ 普 通 譏 } & \multicolumn{3}{|c|}{ 緑 茶 } \\
\hline & & 形状 & 色沢 & 水刍 & 香気 & 滋味 & 計 & 形状 & 色沢 & 水色 & 香気 & 滋味 & 計 & 形状 & 色沢 & 水色 & 香気 & 滋味 & 計。 \\
\hline 5. & 7 & 15 & 15 & 15 & 14 & 14 & 73 & 14 & 14 & 14 & 14 & 14 & 70 & 15 & 15 & 15 & 15 & 14 & 74 \\
\hline 5. & 9 & 14 & 16 & 14 & 15 & 15 & 74 & 14 & 15 & $14^{\circ}$ & 14 & 14 & 71 & 14 & 15. & 15 & 15 & 15 & 73 \\
\hline 7. & 5 & 14. & 14 & 13 & 14 & 13 & 68 & 12 & 13 & 13 & 13 & 13 & 64 & 13 & 14 & 13 & 14 & 13 & 67 \\
\hline 7. & 7 & $14^{\circ}$ & 13 & 12 & 13 & 12 & 64 & 12 & 12 & 12 & 13 & 12 & 61 & 13 & 13 & 12 & 13 & 13. & 64. \\
\hline 8. & 12 & 14 & 13 & 13 & 13 & $13:$ & 66 & 13 & 13 & 12 & 13 & 13 & 64 & 14 & 14 & 13 & 14 & 13 & 68 \\
\hline
\end{tabular}

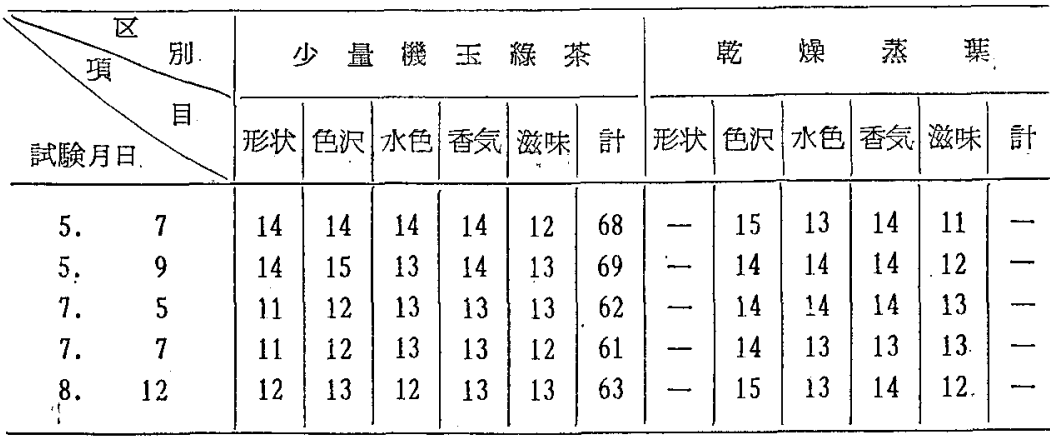

味, 擂潧線茶は滋味の検定飞適 しているように思市れたが， ! の方法も普通審査汇よつて製茶 品留の全頊目について渶足する 成績を求めることは無理であつ。 た。すなわち，乾燥蒸琪伍つ ては水色，湤味があまりにうす

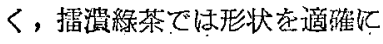
判定できない等で，これ等の判 定は当然特別な基集加证要机な

が求められることを示して灻，形状，水色，香気，滋味 は，ものによつては相関が薄弱で步つたり，その榙定に 多くの不便を感じた。このなかで揉捻綠茶は 㓞状と滋
る。第 3 表は水色，滋味の鑑定に当つて関保する浸出液 濃度を第 1 ，算 2 泰の試料の一部について調べをもので ある。

第 3 表可溶 分 量 単位は鞛物\%

\begin{tabular}{|c|c|c|c|c|c|c|c|c|c|c|}
\hline \multirow{2}{*}{ 別 } & \multirow{2}{*}{ 反覆平蚐 } & \multicolumn{2}{|c|}{ 望 } & 茶 & \multicolumn{2}{|c|}{$\mp$} & 架 & \multirow{2}{*}{ 乾燥蒸琴 } & \multirow{2}{*}{ 擂潰絓茶 } & \multirow{2}{*}{ 揉捻緑茶 } \\
\hline & & 奶 & 照 & 少量蟣 & 対 & 照 & 少量 機 & & & \\
\hline \multirow[b]{2}{*}{1952} & 1 & & - & - & & 29.3 & 24.3 & 10.5 & 26.3 & . 18.6 \\
\hline & 2 & & - & - & & 28.9 & 23.0 & 11.1 & 25.9 & ' 16.8 \\
\hline \multirow{2}{*}{ 5. 9} & 3 & . & - & - & & 28.7 & 23.8 & 11.2 & 25.7 & 19.7 \\
\hline & 平均 & & - & - & & 29.0 & 23.7 & 10.9 & $26: 0$ & 18.4 \\
\hline \multirow[b]{2}{*}{1953.} & 1 & & 28.8, & 27.8 & & 28.6 & 26.5 & 11.8 & - & - \\
\hline & 2 & & 29.1 & 28.2 & & 29.2 & 25.4 & 1.1 .2 & - & - \\
\hline \multirow{2}{*}{5.7} & 3 & & 29.5 & 27.5 & & 28.8 & 26.2 & 10.8 & - & - \\
\hline & 平均 & & 29.1 & 27.8 & & 28.9 & 26.0 & 11.3 & - & - \\
\hline
\end{tabular}

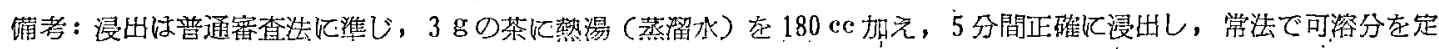
量した。

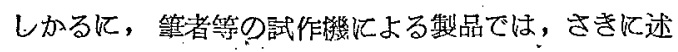

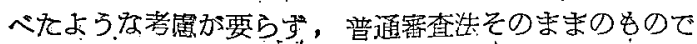
茶の品暨の䐎少，市場洒值等を判断することができた。

\section{2. 製品の沟一性}

同一原料を使つたとき，ある規格限界内で一定の㹕品 の得られることは，比酸試験を行う上の重要なととがら である。これがため同一原料を用いて前茶，玉線茶の両 者を6回反覆製造し，その品貎の变異を普通審查の採点
で調查した。謂查は1953年に一番茶初期の在来種手摘芽 を共試して行つた。

この訊験で変動の大きかつたものは，煎茶では水色に 約 3.5\% ，玉緑茶では湤味に約 $3.0 \%$ 变異俰数を示した が，この程度の変動は問題にする体ごのことはないの で，大体坞一な制造ができるものと劲めた。

4. 整造 $の$. 能淳

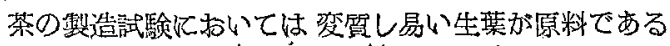




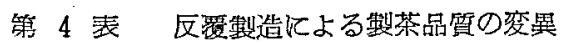

\begin{tabular}{|c|c|c|c|c|c|c|c|c|c|}
\hline 茶の種類 & 項目 & 1 & 2 & 3 & 4 & 5 & 6 & 平均值土標集贀美 & 变異係数 \\
\hline \multirow{6}{*}{ 煎 } & 形 & 14.0 & 13.5 & 14.0 & 14.0 & 14.0 & 14.0 & $13.9 \pm 0.08$ & 0.015 \\
\hline & 色。 & 15.0 & 14.5 & 15.0 & 14.5 & 14.5 & 14.5 & $14.7 \pm 0.11$ & 0.018 \\
\hline & 水 & 15.0 & 14.5 & 15.5 & 16.0 & 15.0 & 15.5 & $15.2 \pm 0.22$ & 0.035 \\
\hline & 香. & 15.0 & 15.0 & 15.5 & 15.5 & 14.5 & 14.5 & $15.0 \pm 0.16$ & 0.026 \\
\hline & 浽 & 15.0 & 14.5 & 15.5 & 15.0 & 15.0 & 15.0 & $15.0 \pm 0.13$ & 0.021 \\
\hline & 喰 点 & 74.0 & 72.5 & 75.5 & 75.0 & 73.0 & 73.5 & $73.9 \pm 0.51$ & 0.017 \\
\hline \multirow{6}{*}{ 玉樂 茶 } & 形 & $14: 0$ & 13.5 & 13.0 & 13.5 & 13.0 & 13.5 & $13.4 \pm 0.15$ & 0.028 \\
\hline & 色 & 15.0 & 15.0 & 14.5 & 14.5 & 15.0 & 15.0 & $14.8 \pm 0.11$ & 0.018 \\
\hline & 水 & 16.0 & 15.5 & 16.0. & 16.5 & 16.0 & 16.5 & $16.1 \pm 0.15$ & 0.023 \\
\hline & 香 & 16.0 & 15.0 & 15.5 & 15.0 & 15.5 & 15.0 & $15.3 \pm 0.17$ & 0.027 \\
\hline & 滋 & 14.0 & 14.0 & 14.0 & 14.5 & 14.0 & $15.0^{\circ}$ & $14.3 \pm 0.17$ & 0.030 \\
\hline & 評点計 & 75.0 & 73.0 & 73.0 & 74.0 & 73.5 & 74.0 & $73.8 \pm 0.28$ & 0.009 \\
\hline
\end{tabular}

ため，短時間に多数の製造の行えることは，単に試呤の 能繴があがるだけでなく，一連の製造試鍳で最初と最後 の投入原料の間仿置されたために 起る品質の变化も少 くなるのでその意義は大きい。第 5 表は刑䒺及び玉線荣 の苩通整法之前記簡易処理法の所要時間を比校しだもの

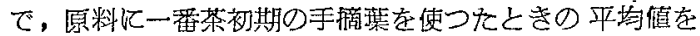
示す。少量誉による製茶法がき和めて能率的であること

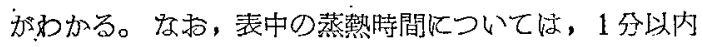
のものはこれを1分に切り上げた。対照の煎茶及び王緣 茶は投入量 3 䨘多を単位とした。

第 5 表 製造所要㭙間

単位 (分)

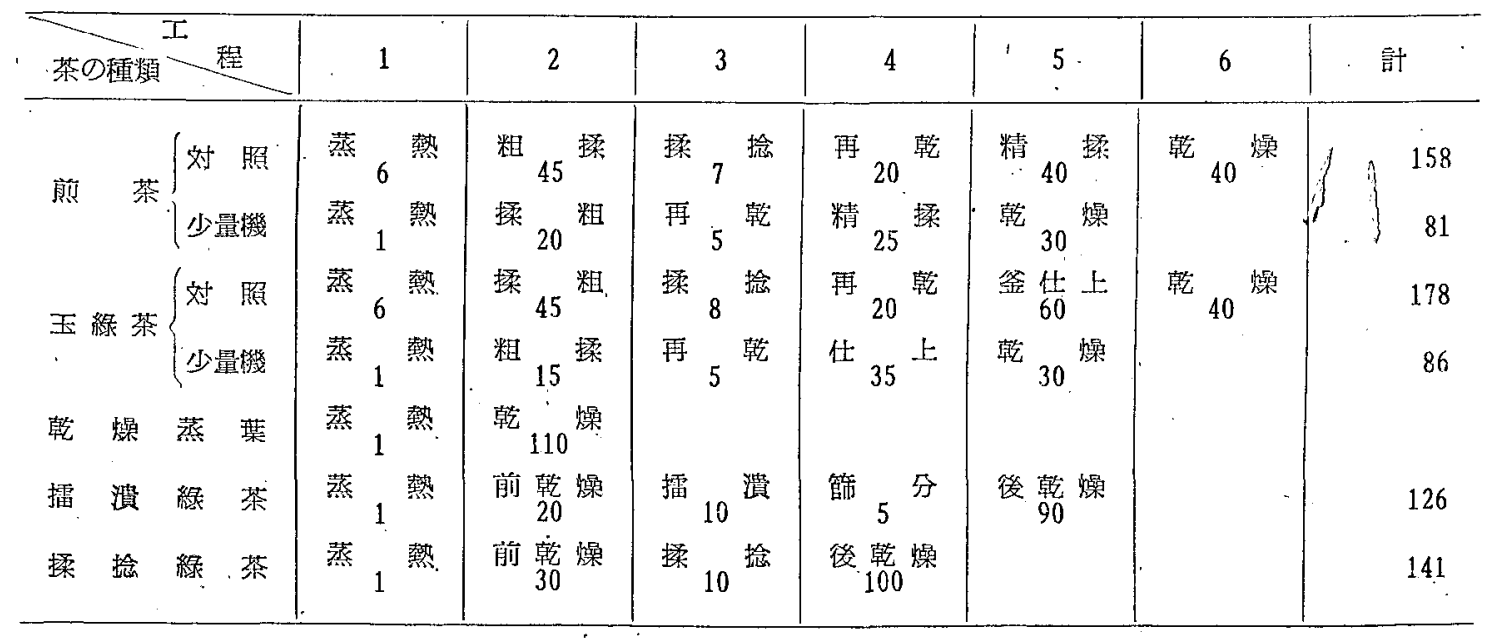

\section{5. 考察之摘要}

少量の茶瑟によつて，簡易汃つ短時間に，缥準㹕の茶 と品質の上で大盖のない茶を造る研究を続けていたが，

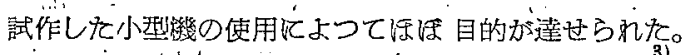
す坎わち，埌来この種の機諓として試みられたものは， 相当量の茶㷊 $(1.0 \sim 1.5 \mathrm{~kg})$ を要し，工程も複雑であつ たが，てれを改善して能率的なものにすることができ

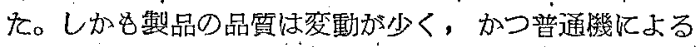

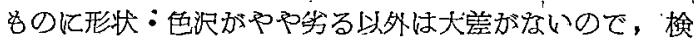
定は普通審查法がそのまま適用できた。ねお，試作機は
その構造上普通製茶機の製作，設訫に奶しても示浚する 点が多く，加熱，迴転，換気等，茶の製造汇必要な条件 もこれを容易に变化することができるので，各工程の基 碟的研究朗も使用できる。

\section{6. 考文献}

1) 桑原穆夫，横沢光雄，鉿木幸隆：茶技研，No. 10, 17 (1954).

2）足立東平：茶鄴組合㓣立50周年記念論文集，第 4 集 (1943).

3) 讃井元：菜業研究発表論文集，20 (1951). 


\section{Summary}

If the qualities of tea made by a miniature process could be estimated as equally as ordinary product, this method would be very useful for tea breeding and manufacturing experiments.

Miniature process machines were designed, matched $200 \sim 300 \mathrm{~g}$. of tea leaves for Sencha and Guri tea, which consisted of a steamer, primary roller, and final roller. The operation of these machines was very easy and the process was time-saving.

The tea produced by this method had the qualities as nearly same as the ordinary products and very small variance within the qualities.

(July 28, 1955)

\title{
茶の遊離才リゴ糖 ${ }^{*}$

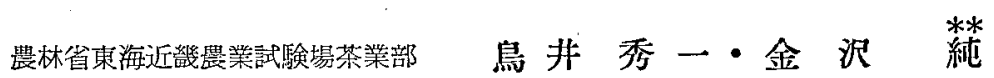

\section{Free Oligosaccharides in the Tea Plant}

\author{
By Hideichi Torit and Jun Kanazawa
}

\section{1.まえがき}

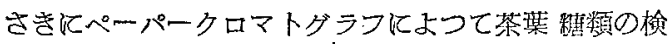
索を試み，その遊嶉䌅としてシュクロース，グルコ一

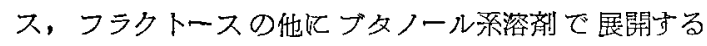
と,シュクロースより Rf 值の低い, オルシン反応陽性 のケトースを含むオリコ絴と考えられる二つのスポット を䗝出した。

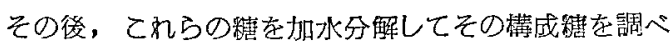
た結果，徉来植物界に見出されているラフィノース，ス タキォースのいすれれもー致しない新しいオリコ䌅であ ることを知つた。

なお, 最近 CARTWRIGHT 及び RoBERTS は製茶の熱 水漫出滩より、フェノール・酢酸・水 $(80: 2: 18)$ とブ タノール・酢酸・水 (4:1:2.2) の二次元クロマトグシ ムによつて, グルコース, フラクトース，シュクロース の他にアラビノース, リボース, ラムノース, ラフィフ 一ス，マルトース定検出したと報じているが，この試料

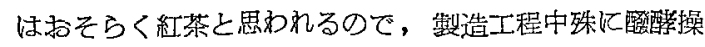
作などでアラビノース，リホーース，ラムノースなどが遊 離上なる可能性各考えられる。末たラフィノース,マル トースについては，彼等の使用した展開剂では他の二䌅 類, 三䅯類が， ラフィノース，マルトースとして同じ位 置老占める盗念も多いと述へている。

\section{2. 実験}

\section{1. 試糊抽出液の調製}

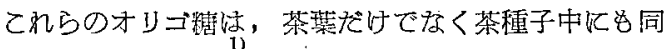

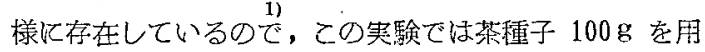
い，㐫らじめエーテルで十分脱脂した後, 既報と同榚 の調製方泆で遊㒕䧽フラタションのシラップ $10 \mathrm{cc}$ を得 to

2. クロマトグ シフ

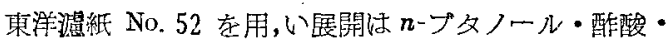
水 $(4: 1: 1)$ の場合洁 4 反覆, $n$-プ及ノール・ピリジ, ン・水 (3:2:1.5) の場合は 3 反琶した。1回の展開距 離は 17〜20 cm, 空温 $\left(10 \sim 15^{\circ} \mathrm{O}\right)$ で上杽法飞よつた。 ペーパークロマトダラム上のスポットの呈色は，ケト 一スにはオルシン試樂を，アルドースにはアニリン試樂 を使用した。検出せられた各スポットの $R f$ 值を純精の それと並心て第 1 表に示す。

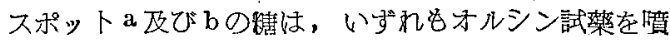
霧して 95 100 $\mathrm{C}$ に10分間加熱すると黃綠色儿呈色す る。e，a，日はそれぞれシェクロース，グルコース，フ ラタトースに相当する。

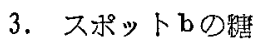

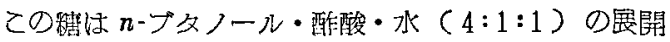
では，紽精（ラフィノース）を添加しても，4回反覆展 